\title{
Tetranortriterpenoids and Dihydrocinnamic Acid Derivatives from Hortia colombiana
}

\author{
Luis E. Cuca Suarez ${ }^{a}$, Francesco Menichini ${ }^{b}$ and Franco Delle Monache ${ }^{*}$ \\ ${ }^{a}$ Depto. de Quimica, Universidad Nacional de Colombia, AA14490, Bogotá, Colombia \\ ${ }^{b}$ Dipto. di Scienze Farmaceutiche, Università della Calabria (Cs), Italy \\ ${ }^{c}$ Centro Chimica dei Recettori del C.N.R., Istituto di Chimica, U.C.S.C., Largo F.Vito 1, 00168 Roma, Italy
}

\begin{abstract}
Dois tetranortriterpenos, sendo um inédito e dois novos derivados do acido dihidrocinâmico foram obtidos da madeira de Hortia colombiana. Suas estruturas foram elucidadas por RMN, e as configurações relativas estabelecidas através de experimentos de nOe diferencial. Em adição, foram isolados aloxantoxiletina, nerolidol, epoxinerolidol, três conhecidos derivados do acido dihidrocinâmico e duas amidas.
\end{abstract}

A novel tetranortriterpenoid and two dihydrocinnamic acid derivatives were obtained from the wood of Hortia colombiana. Their structures were elucidated by detailed NMR investigations and the relative configurations established by Difference NOE experiments. In addition, alloxanthoxyletin, nerolidol, epoxynerolidol, three known dihydrocinnamic acid derivatives and two amides were isolated. Detailed analysis of NMR data of Hortiolide A, whose structure was previosly established by $\mathrm{X}$ ray, are also provided.

Keywords: Hortia colombiana, Rutaceae, dihydrocinnamic acid derivatives, sesquiterpenes, coumarin, amides, limonoids, Hortiolide A and B

\section{Introduction}

The Rutaceae family is a source of alkaloids, coumarins, flavonoids and limonoids. ${ }^{1}$ During a search on Colombian Rutaceae we reported earlier ${ }^{2}$ the alkaloidal components isolated from the bark and wood of Hortia colombiana, collected in the Chocó Department (Colombia), one of the most humid regions of the world. ${ }^{3}$

Detailed examination of the wood extract allowed now the isolation of five dihydrocinnamic acid derivatives, two sesquiterpenes, one coumarin, two amides and two limonoids. One tetranortriterpenoid and two of the dihydrocinnamic acid derivatives are new compounds. This paper deals with the isolation of the above secondary metabolites and the structural elucidation of the new compounds.

\section{Results and Discussion}

Conventional chromatographic separation of the methanolic extract of the wood afforded five alkaloids, ${ }^{2}$

* e-mail: f.dellemonache@uniserv.ccr.rm.cnr.it five dihydrocinnamic acid derivatives (1-5), alloxanthoxyletin $\mathbf{7}$, two sesquiterpenes (8-9), two amides (10-11) and two limonoids (12-13).

Compounds 1-3 have been previously reported ${ }^{4-6}$ from other Hortia spp, while the acid $\mathbf{4}$ and its methylester $\mathbf{5}$ are novel compounds. Unequivocal assignement of the ${ }^{13} \mathrm{C}$ NMR parameters of compounds 1-5 were obtained by HETCOR and Long-range HETCOR experiments, and are reported in Table 1. The data for $\mathbf{1}$ are coincident with those previously reported, ${ }^{5}$ whilst the assignments of the C-6, C-8 and C-9 signals for 3 have been corrected with respect to the literature ${ }^{6}$ on the basis of selective INEPT experiments (see Experimental).

The ${ }^{13} \mathrm{C}$ NMR data of $\mathbf{2}$ are here reported for the first time and it should be underlined that the value $(\delta 19.0)$ for

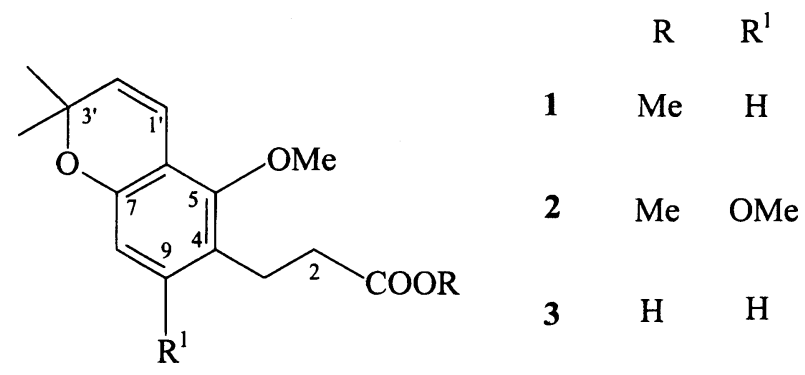


Table 1. ${ }^{13} \mathrm{C}$ NMR data of dihydrocinnamic acid derivatives 1-5

\begin{tabular}{crrrrr}
\hline Carbon & \multicolumn{1}{c}{$\mathbf{1}$} & \multicolumn{1}{c}{$\mathbf{2}$} & \multicolumn{1}{c}{$\mathbf{3}$} & \multicolumn{1}{c}{$\mathbf{4}$} & \multicolumn{1}{c}{$\mathbf{5}$} \\
\hline 1 & 173.7 & 174.1 & 179.3 & 178.7 & 173.6 \\
2 & 34.9 & 34.1 & 34.9 & 35.0 & 35.1 \\
3 & 24.9 & 19.0 & 24.7 & 24.9 & 25.1 \\
4 & 125.1 & 113.9 & 124.8 & 123.8 & 124.1 \\
5 & 152.5 & 153.0 & 154.2 & 147.8 & 147.8 \\
6 & 114.8 & 107.6 & 114.0 & 115.6 & 115.6 \\
7 & 154.3 & 155.1 & 152.6 & 141.2 & 141.1 \\
8 & 112.3 & 95.8 & 112.3 & 144.7 & 144.7 \\
9 & 129.4 & 158.7 & 129.4 & 113.0 & 113.1 \\
1, & 117.2 & 113.9 & 117.2 & 117.3 & 117.4 \\
2 & 130.4 & 127.1 & 130.4 & 130.6 & 130.6 \\
3, & 75.6 & 76.0 & 75.6 & 75.8 & 75.8 \\
$4,, 5$ & 27.7 & 27.7 & 27.7 & 27.5 & 27.6 \\
$1-\mathrm{OMe}$ & 51.6 & 51.5 & - & - & 51.6 \\
$5-\mathrm{OMe}$ & 62.1 & 62.4 & 62.0 & 62.2 & 62.2 \\
$8-\mathrm{OMe}$ & - & - & - & 56.5 & 56.5 \\
$9-\mathrm{OMe}$ & - & 55.5 & - & - & - \\
\hline
\end{tabular}

carbon 3 is quite different from the corresponding values $(\delta$ 24.7-25.1) for the other derivatives (Table 1) due to the adjacent aromatic ring ortho-dioxigenation.

In the ${ }^{1} \mathrm{H}$ NMR spectrum the ester $\mathbf{5}$ exhibited signals for an aromatic proton, a chromene moiety and two aromatic methoxy group suggesting it is an isomer of $\mathbf{2}$. Only one of the methoxyls $\left(\delta_{\mathrm{C}} 62.2 ; \delta_{\mathrm{H}} 3.71\right)$ was orthodisubstituted ${ }^{7,8}$ and in the selective INEPT experiments, the irradiation of the benzylic methylene signal $(\delta 2.88)$ gave response, inter alia, for the protonated aromatic carbon ( $\delta$ 113.1) leaving only the structures $\mathbf{5}$ or $\mathbf{6}$ for the compound. The structure $\mathbf{5}$ was definitively established by difference nOe experiments. Irradiation of the methylene signal $(\delta 2.88)$ gave nOe effects on both the aromatic proton and the 5 -OMe $(\delta 3.71)$ signals, while irradiation at $\delta 3.71$ enhanced the same methylene and $\mathrm{H}-1$ ' $(\delta$ 6.55); on the<smiles>COc1cc(CCC(=O)O[Na])c(OC)c2c1OC(C)(C)C=C2</smiles><smiles>COc1cc(CCC(C)=O)c(OC)c2c1C=CC(C)(C)O2</smiles>

contrary, the irradiation at $\delta 3.82(8-\mathrm{OMe})$ showed a nOe effect only on the aromatic proton.

Alloxanthoxyletin (7) exhibited in the ${ }^{1} \mathrm{H}$ NMR spectrum the appropriate signals for a coumarin $\left(\delta_{\mathrm{H}} 7.96\right.$ and 6.12) with a methoxy group $\left(\delta_{\mathrm{C}} 55.9\right)$ and a chromene ring. The other three possible known isomeric coumarin structures, ${ }^{9}$ i.e. xanthoxyletin, luvangetin and braylein, were discarded due to either the presence of an ortho-disubstituted OMe (xanthoxyletin and luvangetin) or to the absence of any oxygenated substituent on C-5 (braylein). ${ }^{10}$<smiles>COc1cc2oc(=O)ccc2c2c1C=CC(C)(C)O2</smiles>

Nerolidol, $\mathbf{8}$, epoxynerolidol, $\mathbf{9}$, as well as the amides $\mathbf{1 0}^{11}$ and $\mathbf{1 1}$ were identified on the basis of their NMR spectral data (see Experimental).

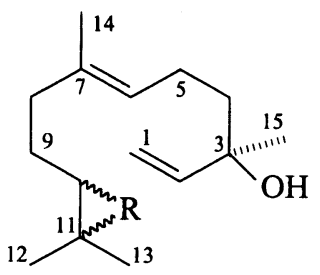

R

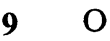

$\mathbf{R}$<smiles>[R20]c1ccc(CCNC(=O)C(C)=CC)cc1</smiles>

10<smiles>C[C]C=C(C)C</smiles>

11

$\mathrm{H}$

The structure 12 for the isolated limonoid named Hortiolide A was initially established by MS and NMR data, subsequently confirmed by single-crystal method. ${ }^{12}$ The detailed analysis of the spectral data is reported here. Hortiolide A was obtained as a dextrorotatory solid and assigned the molecular formula $\mathrm{C}_{27} \mathrm{H}_{32} \mathrm{O}_{7}$ on the basis of EIMS and NMR evidences. The intense ion at $\mathrm{m} / \mathrm{z} 372$ $\left(\mathrm{M}^{+}-\mathrm{C}_{5} \mathrm{H}_{4} \mathrm{O}_{2}\right)$ is characteristic of limonoids possessing a furan ring attached to the $\alpha, \beta$-unsaturated lactonic $\mathrm{D}$ ring. ${ }^{13}$ The presence of the furan ring was confirmed by the characteristic signal patterns in the ${ }^{1} \mathrm{H}$ NMR and appropriate carbon signals in ${ }^{13} \mathrm{C}$ NMR spectra. The assignment of each NMR signal to the pertinent proton 


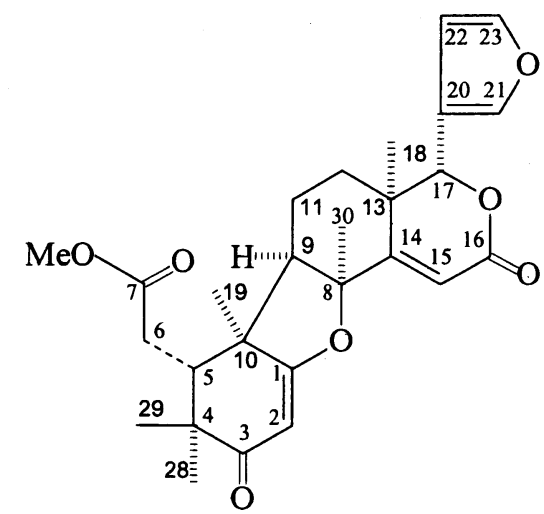

12

and carbon was achieved by HETCOR measurements, while that of quaternary carbons followed from the longrange correlations and are reported in Table 2 . In addition, important $\mathrm{H}-\mathrm{C}$ long-range correlations were obtained by selective INEPT experiments (Table 3 ).

Examination of the NMR data, mainly the long-range correlations, indicated that, in addition to the furan moiety, hortiolide A contained well-defined A, C and D rings as depicted in 12. For instance, for ring D long-range

Table 2. NMR spectral data for Hortiolide A (12)*

\begin{tabular}{|c|c|c|c|}
\hline $\mathrm{H} / \mathrm{C}$ & $\delta_{\mathrm{H}}$ & $\delta_{\mathrm{C}}$ & $\begin{array}{c}\text { Long Range } \\
\text { C-H connectivities }\end{array}$ \\
\hline 1 & - & 179.7 & Me-19 \\
\hline 2 & $5.44 \mathrm{~s}$ & 101.3 & \\
\hline 3 & - & 202.2 & $\mathrm{Me}-28, \mathrm{Me}-29$ \\
\hline 4 & - & 44.3 & Мe-28, Мe-29, H-5, H-6 \\
\hline 5 & $2.56 \mathrm{dd}(10,1.6)$ & 42.3 & Мe-19, Мe-28, Мe-29 \\
\hline 6 & $\begin{array}{l}2.70 \mathrm{dd}(15.5,10.0) \\
2.27 \mathrm{dd}(15.5,1.6)\end{array}$ & 32.6 & $\mathrm{H}-5$ \\
\hline 7 & - & 173.2 & $\mathrm{H}-6$, OMe \\
\hline $\mathrm{OMe}$ & $3.72 \mathrm{~s}$ & 52.0 & \\
\hline 8 & - & 89.3 & $\mathrm{Me}-30$ \\
\hline 9 & $2.11 \mathrm{dd}(12.7,4.4)$ & 56.4 & \\
\hline 10 & - & 48.0 & Мe-19, Н-5, Н-6 \\
\hline 11 & $1.78 \mathrm{~m}$ & 21.8 & \\
\hline 12 & $\begin{array}{c}1.93(13,4.5) \\
1.12 \mathrm{~m}\end{array}$ & 30.3 & $\mathrm{Me}-18$ \\
\hline 13 & - & 37.7 & $\mathrm{Me}-18, \mathrm{H}-15$ \\
\hline 14 & - & 167.1 & $\mathrm{Me}-18, \mathrm{Me}-30, \mathrm{H}-12$ \\
\hline 15 & $6.37 \mathrm{~s}$ & 116.0 & \\
\hline 16 & - & 164.3 & H-15 \\
\hline 17 & $5.20 \mathrm{~s}$ & 78.9 & $\mathrm{Me}-18$ \\
\hline 18 & $1.20 \mathrm{~s}$ & 20.9 & H-17 \\
\hline 19 & $1.50 \mathrm{~s}$ & 25.8 & $\mathrm{H}-5, \mathrm{H}-9$ \\
\hline 20 & - & 119.6 & H-2 1 \\
\hline 21 & 7.53 br s & 142.0 & $\mathrm{H}-22, \mathrm{H}-17$ \\
\hline 22 & 6.50 br s & 110.4 & H-23 \\
\hline 23 & 7.45 br t (1.7) & 143.0 & $\mathrm{H}-22, \mathrm{H}-21$ \\
\hline 28 & $1.22 \mathrm{~s}$ & 22.7 & $\mathrm{Me}-29, \mathrm{H}-5$ \\
\hline 29 & $1.07 \mathrm{~s}$ & 27.0 & $\mathrm{Me}-28, \mathrm{H}-5$ \\
\hline 30 & $1.82 \mathrm{~s}$ & 31.1 & \\
\hline
\end{tabular}

*In $\mathrm{CDCl}_{3} .{ }^{1} \mathrm{H}(300 \mathrm{MHz}),{ }^{13} \mathrm{C}(75 \mathrm{MHz})$. Coupling constants (in $\left.\mathrm{Hz}\right)$ in parentheses
Table 3. Selective INEPT experiments on Hortiolide A (12)

\begin{tabular}{lcc}
\hline Irradiated proton & \multicolumn{2}{c}{ Connected Carbons } \\
& ${ }^{3} J$ & ${ }^{2} J$ \\
\hline H-2 (5.44) & C-4, C-10 & C-1 \\
H-5 (2.56) & C-1, Me-19 & C-4, C-10 \\
H-9 (2.11) & C-7, Me-19 & \\
H-15 (6.37) & C-8, C-13 & C-14, C-16 \\
H-17 (5.20) & C-14, C-21, C-22, Me-18 & C-20 \\
Me-19 (1.50) & C-1, C-5, C-9 & C-10 \\
Me-29 (1.07) & C-3, C-5, Me-28 & C-4 \\
\hline
\end{tabular}

connectivities were found for $\mathrm{H}-17\left(\delta_{\mathrm{H}} 5.20 \mathrm{~s} ; \delta_{\mathrm{C}} 78.9\right)$ with C-20, C-21, C-22 (furan ring), C-14 and Me-18; for $\mathrm{H}-15\left(\delta_{\mathrm{H}} 6.37 \mathrm{~s} ; \delta_{\mathrm{C}} 116.0\right)$ with C-8, C-13, C-14 and C-16. In the turn, for ring $\mathrm{A}, \mathrm{H}-2\left(\delta_{\mathrm{H}} 5.44 \mathrm{~s} ; \delta_{\mathrm{C}} 101.3\right)$ correlated with C-1, C-4 and C-10; H-5 $\left(\delta_{\mathrm{H}} 2.56 \mathrm{dd} ; \delta_{\mathrm{C}} 42.3\right)$ correlated with C-4, C-7, C-10 and Me-19. Finally, for ring C, important correlations were found between $\mathrm{H}-9\left(\delta_{\mathrm{H}} 2.80\right.$ $\left.\mathrm{dd} ; \delta_{\mathrm{C}} 45.9\right)$ and $\mathrm{C}-1$ and Me-19. Cumulatively, the above data led to the structure $\mathbf{1 2}$ for hortiolide A, which was definitively confirmed by an $\mathrm{X}$ ray diffraction study. ${ }^{12}$

To the oily Hortiolide $\mathrm{B}, \mathrm{C}_{27} \mathrm{H}_{30} \mathrm{O}_{8}$, i.e. containing one oxygen and one unsaturation or cycle more than hortiolide A, was assigned the structure 13. The unequivocal assignments of NMR signals are reported in Tables 4 and 5 , as a result of 1D- and 2D-NMR experiments. Comparison with the data of hortiolide A suggested the presence of furan and the same $\mathrm{D}$ ring.<smiles>COC(=O)CC1C(C)(C)C(=O)[C@@H]2O[C@@]23O[C@@]2(C)C4=CC(=O)O[C@H](c5ccoc5)[C@@]4(C)CC=C2[C@]13C</smiles>

13

Upon treatment with acetic anhydride and pyridine the compound was recovered unaltered suggesting the extra oxygen may be part of an epoxide. In accordance, in the ${ }^{13} \mathrm{C}$ NMR spectrum there are a singlet at $\delta 116.6$ and a doublet at $\delta 70.6$, the latter ${ }^{1} J$ correlated to a singlet at $\delta$ 5.26 , which were attributed to the hemiacetalic $\mathrm{C}-1$ and to the epoxidic C-2, respectively. Accordingly, long-range correlations were found between C-1 and Me-19 (Table 3), and between $\mathrm{H}-2$ and $\mathrm{C}-1$ (Table 4). The trisubstituted 
Table 4. NMR spectral data for Hortiolide B (13)*

\begin{tabular}{|c|c|c|c|}
\hline $\mathrm{H} / \mathrm{C}$ & $\delta_{\mathrm{H}}$ & $\delta_{\mathrm{C}}$ & $\begin{array}{c}\text { Long Range } \\
\text { C-H connectivities }\end{array}$ \\
\hline 1 & - & 116.7 & $\mathrm{Me}-19$ \\
\hline 2 & $5.26 \mathrm{~s}$ & 70.6 & \\
\hline 3 & - & 202.7 & $\mathrm{Me}-28, \mathrm{Me}-29$ \\
\hline 4 & - & 45.2 & Me-28, Мe-29 \\
\hline 5 & $2.88 \mathrm{dd}(7.0,3.5)$ & 45.9 & \\
\hline \multirow[t]{2}{*}{6} & $2.64 \mathrm{dd}(17.0,7.0)$ & 30.3 & \\
\hline & $2.53 \mathrm{dd}(17.0,3.5)$ & & \\
\hline 7 & - & 174.0 & \\
\hline $\mathrm{OMe}$ & $3.66 \mathrm{~s}$ & 52.1 & \\
\hline 8 & - & 64.7 & $\mathrm{H}-11$ \\
\hline 9 & - & 141.4 & Me-19 \\
\hline 10 & - & 43.6 & Me-19 \\
\hline 11 & $5.78 \mathrm{t}(2.4)$ & 131.5 & $\mathrm{H}_{2}-12$ \\
\hline \multirow[t]{2}{*}{12} & $2.37 \mathrm{dd}(18.0,2.4)$ & 42.0 & \\
\hline & $2.18 \mathrm{dd}(18.0,2.4)$ & & \\
\hline 13 & - & 48.5 & $\mathrm{H}-11, \mathrm{Me}-18$ \\
\hline 14 & - & 175.7 & $\mathrm{Me}-30$ \\
\hline 15 & $5.93 \mathrm{~s}$ & 116.6 & \\
\hline 16 & - & 168.7 & \\
\hline 17 & $5.17 \mathrm{~s}$ & 79.1 & $\mathrm{Me}-18, \mathrm{H}-12$ \\
\hline 18 & $1.42 \mathrm{~s}$ & 16.8 & \\
\hline 19 & $1.55 \mathrm{~s}$ & 25.0 & \\
\hline 20 & - & 120.1 & $\mathrm{H}-21$ \\
\hline 21 & 7.45 br s & 141.6 & $\mathrm{H}-23$ \\
\hline 22 & $6.46 \mathrm{t}(1.5)$ & 110.2 & \\
\hline 23 & 7.45 br s & 143.2 & \\
\hline 28 & $1.22 \mathrm{~s}$ & 22.7 & \\
\hline 29 & $1.20 \mathrm{~s}$ & 28.3 & \\
\hline 30 & $1.73 \mathrm{~s}$ & 24.3 & \\
\hline
\end{tabular}

*See footnote in Table 2

Table 5. Selective INEPT experiments on Hortiolide B (13)

\begin{tabular}{lcc}
\hline Irradiated proton & \multicolumn{2}{c}{ Connected Carbons } \\
& \multicolumn{2}{c}{${ }^{3} J$} \\
\hline $\mathrm{H}-2(5.26)$ & $\mathrm{C}-7, \mathrm{Me}-28$ & $\mathrm{C}-1$ \\
$\mathrm{H}-5(2.88)$ & $\mathrm{C}-10$ & $\mathrm{C}-4, \mathrm{C}-10$ \\
$\mathrm{H}-6(2.64)$ & $\mathrm{C}-8, \mathrm{C}-13$ & $\mathrm{C}-5, \mathrm{C}-7$ \\
$\mathrm{H}-11(5.78)$ & $\mathrm{C}-9, \mathrm{C}-17$ & $\mathrm{C}-9, \mathrm{C}-12$ \\
$\mathrm{H}-12(2.18)$ & $\mathrm{C}-8, \mathrm{C}-13$ & $\mathrm{C}-11, \mathrm{C}-13$ \\
$\mathrm{H}-15(5.93)$ & $\mathrm{C}-21, \mathrm{C}-22, \mathrm{Me}-18$ & $\mathrm{C}-14$ \\
$\mathrm{H}-17(5.17)$ & $\mathrm{C}-12, \mathrm{C}-14, \mathrm{C}-17$ & $\mathrm{C}-13, \mathrm{C}-20$ \\
$\mathrm{Me}-18(1.42)$ & $\mathrm{C}-5, \mathrm{C}-9$ & $\mathrm{C}-10$ \\
$\mathrm{Me}-19(1.55)$ & & $\mathrm{C}-8$ \\
$\mathrm{Me}-30(1.73)$ & & \\
\hline
\end{tabular}

double bond, $\delta_{\mathrm{C}} 141.4$ and $\delta_{\mathrm{C}} 131.5\left(\delta_{\mathrm{H}} 5.78 \mathrm{t}\right)$, was localized to position 9(11) on the basis of long-range correlations. In fact, in the selective INEPT experiments (Table 5), H-11 showed ${ }^{3} J$ correlations with $\mathrm{C}-8$ and $\mathrm{C}-13$, and ${ }^{2} J$ correlations with $\mathrm{C}-9$ and $\mathrm{C}-12$; in turn, the methylene on position $12\left(\delta_{\mathrm{C}} 42.0 ; \delta_{\mathrm{H}} 2.37 \mathrm{dd}\right.$ and 2.18 dd) was correlated to C-9 and C-17. On the other side, in the long-range HETCOR spectrum, C-9 showed a cross peak with the Me-19. Other long-range correlations (Tables 4 and 5) agreed with the proposed structure 13.

Assignements of the relative configurations at the seven chiral centers were established by difference nOe experiments. Thus, the selective irradiation at $\delta 1.42$ (Me18 ) enhanced the signal for Me-30, and irradiation at $\delta$ 1.55 (Me-19) gave responce for Me-28 and the methylene on position 6 ( $\alpha$ side of the molecule); while the selective irradiation at $\delta 2.88(\mathrm{H}-5)$ enhanced both signals attributed to $\mathrm{H}-2$ and Me-29 ( $\beta$ side), giving further support to the structure 13.

The occurrence of tetranortriterpenoids is limited to the Rutales order comprising Meliaceae, Cneoraceae, Rutaceae and Simarubaceae. ${ }^{1}$ This class of compounds is biogenetically derived from $\Delta^{7}$-euphol/tirucallol by oxidative degradation of the $\mathrm{C}-17$ side chain resulting in the loss of four carbon atoms and formation of the $\beta$-substituted furan. Successive oxidations and skeletal rearrangements of one or more the carbocyclic rings of the precursor lead to a great variety of biologically active compounds, mainly in Meliaceae. ${ }^{14-16}$ The structural variations of limonoids found in Rutaceae are less than in Meliaceae and are generally limited to the modification of $\mathrm{A}$ and $\mathrm{B}$ rings. ${ }^{1}$

It is whortnoting that only one tetranortriterpenoid has previously been reported from the genus Hortia. ${ }^{5}$ Hortiolide $\mathrm{A}$ and $\mathrm{B}$ represent new structural types, which may be biogenetically derived from $\mathrm{B}$ ring seco limonoids of the so called Group $4 .{ }^{16}$ In addition, both have the rare 1,8 epoxy linkage, which has been noted before in Utilin $\mathrm{C}^{17}$ isolated from Meliaceae.

\section{Experimental}

${ }^{1} \mathrm{H}$ and ${ }^{13} \mathrm{C}$ NMR $\left(\mathrm{CDCl}_{3}\right): 300 \mathrm{MHz}$ and $75 \mathrm{MHz}$, respectively. EIMS; direct inlet, $70 \mathrm{eV}$. Optical rotations $\left(\mathrm{CHCl}_{3}\right)$.

\section{Plant material}

Hortia colombiana Gleason (Rutaceae) was collected in June 1990 near Quibdó (Depto. Chocó, Colombia) and identified by Dr. R. Jaramillo Mejia (Instituto de Ciencias Naturales, Universidad Nacional de Colombia). A voucher (COL 364815) is deposited in the Herbario Nacional Colombiano, Bogotá.

\section{Extraction and fractionation}

Roughly ground wood $(5.2 \mathrm{~kg})$ was extracted in a Soxhlet apparatus $(12 \mathrm{~h}$ ) with EtOH and the extract evaporated. Part $(18 \mathrm{~g})$ of the $\mathrm{CHCl}_{3}$ soluble portion $(84 \mathrm{~g})$ was 
chromatographed on silica gel column with toluene/ethyl acetate, 9/1 (v/v), affording seven fractions: W-1 (4 g), W-2 (3.4 g), W-3 (3.5 g), W-4 (0.6 g), W-5 (0.9 g), W-6(1.6 g), W-7 (3 g). Repeated CC of each fraction yielded 1 (160 mg), 2 (40 $\mathrm{mg})$, alloxanthoxyletin, 7 (400 $\mathrm{mg}$ ) and impure nerolidol from $\mathrm{W}-1$; a mixture (1, 2 and 7), epoxynerolidol, 9 (20 mg), nerolidol, $8(800 \mathrm{mg}), \mathbf{5}(40 \mathrm{mg})$ and oleic acid $(130 \mathrm{mg})$ from $\mathrm{W}-2 ; 3$ (1.3 g), N-methylflindersiamine (120 mg), 10 (170 $\mathrm{mg}), \mathbf{1 1}(20 \mathrm{mg})$ from $\mathrm{W}-3$; a mixture (3 and 10), hortiolide B, $13(120 \mathrm{mg})$ and 4 (50 mg) from W-4; impure 4, hortiolide A, $12(120 \mathrm{mg})$ and a mixture (skimianine and $\gamma$-fagarine) from $\mathrm{W}-5$; impure 4 and 11, flindersine, 2,4-dimethoxyquinoline and a mixture of skimianine and $\gamma$-fagarine from $\mathrm{W}-6$. W-7 was not further processed.

Methyl 3-[2-methoxy-6',6'-dimethylpyrano(2',3':3,4) phenyl]-propionate (1)

Oil. ${ }^{1} \mathrm{H}$ NMR (300 MHz, $\left.\mathrm{CDCl}_{3}\right): \delta 6.92(1 \mathrm{H}, \mathrm{d}, J 8.3$ Hz, H-9), $6.56(1 \mathrm{H}, \mathrm{d}, J 10 \mathrm{~Hz}, \mathrm{H}-1$ '), $6.52(1 \mathrm{H}, \mathrm{d}, J 8.3 \mathrm{~Hz}$, H-8), 5.63 (1H, d, J 10 Hz , H-2'), 3.75 (3H,s, 5-OMe), 3.68 (3H,s, 1-OMe), 2.86 (2H, t, J 7.5 Hz, H-3), 2.59 (2H,t, J 7.5 Hz, H-2), 1.42 (6H, s, Me'2). ${ }^{13} \mathrm{C}$ NMR in Table 1.

Methyl 3-[2,6-dimethoxy-6',6'-dimethylpyrano(2',3':3,4)phenyl]-propionate (2)

Oil. ${ }^{1} \mathrm{H}$ NMR $\left(300 \mathrm{MHz}, \mathrm{CDCl}_{3}\right): \delta 6.49(1 \mathrm{H}, \mathrm{d}, J 10.0$ Hz, H-1'), 6.19 (1H, s, H-8), 5.48 (2H, d, J10Hz, H-2'), 3.76 (3H, s, 9-OMe), 3.73 (3H, s, 5-OMe), 3.68 (3H, s, 1-OMe), 2.87 (2H, t, J 7.5 Hz, H-3), 2.50 (2H, t, J $7.5 \mathrm{~Hz}, \mathrm{H}-2)$, $1.42\left(6 \mathrm{H}, \mathrm{s}, \mathrm{Me}^{\prime} 2\right) .{ }^{13} \mathrm{C}$ NMR see Table 1.

3-[2,6-dimethoxy-6', 6'-dimethylpyrano(2',3 ':3,4)phenyl]-propionic acid (3)

mp 164-6 ${ }^{\circ} \mathrm{C} .{ }^{1} \mathrm{H}$ NMR $\left(300 \mathrm{MHz}, \mathrm{CDCl}_{3}\right): \delta 10.1(1 \mathrm{H}$, br s, COOH), $6.93(1 \mathrm{H}, \mathrm{d}, J 8.3 \mathrm{~Hz}, \mathrm{H}-9), 6.56(1 \mathrm{H}, \mathrm{d}, J 10$ Hz, H-1'), 6.53 (1H, d, J 8.3 Hz, H-8), 5.64 (1H, d, J $10 \mathrm{~Hz}$, H-2'), 3.75 (3H, s, OMe), 2.88 (2H, t, J 7.5 Hz, H-3), 2.65 $(2 \mathrm{H}, \mathrm{t}, J 7.5 \mathrm{~Hz}, \mathrm{H}-2), 1.42\left(6 \mathrm{H}, \mathrm{s}, \mathrm{Me}^{\prime} 2\right) .{ }^{13} \mathrm{C}$ NMR see Table 1 . In the selective INEPT experiments correlations were found inter alia between: $\mathrm{H}-9(\delta 6.93)$ and $\mathrm{C}-3, \mathrm{C}-5$, C-7; H-8 ( $\delta$ 6.53) and C-4, C-6; 5-OMe $(\delta$ 3.75) and C-5; $\mathrm{H}_{2}-3(\delta 2.88)$ and C-1, C-5, C-9.

\section{3-[2,5-dimethoxy-6',6'-dimethylpyrano(3',2':3,4)-phenyl- propionic acid (4)}

mp 117-8 ${ }^{\circ} \mathrm{C}$. Anal. Calcd. for $\mathrm{C}_{16} \mathrm{H}_{20} \mathrm{O}_{5}: \mathrm{C}, 65.74 ; \mathrm{H}$, 6.90. Found: C, 65.62; H, 7.00. ${ }^{1} \mathrm{H} \mathrm{NMR}\left(300 \mathrm{MHz}, \mathrm{CDCl}_{3}\right)$ : $\delta 9.8(1 \mathrm{H}$, br s, COOH $), 6.60(1 \mathrm{H}, \mathrm{s}, \mathrm{H}-9), 6.55(1 \mathrm{H}, \mathrm{d}, J 10$ Hz, H-1'), 5.65 (1H, d, J 10 Hz, H-2'), 3.82 (3H, s, 8-OMe), $3.71(3 \mathrm{H}, \mathrm{s}, 5-\mathrm{OMe}), 2.88(2 \mathrm{H}, \mathrm{t}, J 7.5 \mathrm{~Hz}, \mathrm{H}-3), 2.65$ (2H, t, $J 7.5 \mathrm{~Hz}, \mathrm{H}-2), 1.47$ (6H, s, Me'2). ${ }^{13} \mathrm{C}$ NMR see Table 1.

Methyl 3 -[2,5-dimethoxy-6',6'-dimethylpyrano(3',2':3,4)phenyl-propionate (5)

Oil. Anal.Calcd. for $\mathrm{C}_{17} \mathrm{H}_{22} \mathrm{O}_{5}$ : C, 66.65; H, 7.24. Found: C, 66.50; H, 7.32. ${ }^{1} \mathrm{H}$ NMR $\left(300 \mathrm{MHz} \mathrm{CDCl}_{3}\right): \delta$ $6.59(1 \mathrm{H}, \mathrm{s}, \mathrm{H}-9), 6.55(1 \mathrm{H}, \mathrm{d}, J 10 \mathrm{~Hz}, \mathrm{H}-1$ '), $5.65(1 \mathrm{H}, \mathrm{d}$, $J 10 \mathrm{~Hz}, \mathrm{H}-2$ '), 3.82 (3H, s, 8-OMe), 3.71 (3H, s, 5-OMe), $3.68(3 \mathrm{H}, \mathrm{s}, 1-\mathrm{OMe}), 2.88(2 \mathrm{H}, \mathrm{t}, J 7.5 \mathrm{~Hz}, \mathrm{H}-3), 2.62(2 \mathrm{H}, \mathrm{t}$, J7.4 Hz, H-2), 1.47 (6H, s, Me'2). ${ }^{13} \mathrm{C}$ NMR see Table 1. In the Long Range HETCOR spectrum C-1 ( $\delta$ 173.6) correlates with 1-OMe; C-5 $(\delta$ 147.8) with H-9; C-6 $(\delta$ 115.6) with H-1' and H-9; C-7 ( $\delta$ 141.1) with H-2'; C-8 $(\delta$ 144.7) with 8-OMe. In the selective INEPT experiments correlations were found between $8-\mathrm{OMe}(\delta 3.82)$ and $\mathrm{C}-8$; and between $\mathrm{H}_{2}-3(\delta$ 2.88) and $\mathrm{C}-1, \mathrm{C}-4, \mathrm{C}-5$ and $\mathrm{C}-9$. Difference nOe experiments: mutual nOe effects were observed between $\mathrm{H}_{2}-2, \mathrm{H}-9$, and 5-OMe; between 5-OMe and $\mathrm{H}-1$ '; between $\mathrm{H}-9$ and 8-OMe.

\section{Alloxanthoxyletin (7)}

mp $114-5^{\circ} \mathrm{C} .{ }^{1} \mathrm{H} \mathrm{NMR}\left(300 \mathrm{MHz}, \mathrm{CDCl}_{3}\right): \delta 7.96(1 \mathrm{H}$, d, J 9.7 Hz, H-4), 6.79 (1H, d, J $10 \mathrm{~Hz}, \mathrm{H}-1^{\prime}$ '), $6.23(1 \mathrm{H}, \mathrm{s}$, $\mathrm{H}-8), 6.12$ (1H, d, J 9.7, H-3), $5.58(1 \mathrm{H}, \mathrm{d}, J 10 \mathrm{~Hz}$, H-2'), 3.89 (3H, s, OMe), 1.46 (6H, s, Me'2). ${ }^{13} \mathrm{C} \mathrm{NMR} \mathrm{(75}$ $\left.\mathrm{MHz}, \mathrm{CDCl}_{3}\right): \delta 161.3$ (C-2), 157.4, 156.5 (C-7, C-8a), 151.0 (C-5), 139.0 (C-4), 127.5 (C-2'), 115.0 (C-1') 110.4 (C-3), 103.6, 102.6 (C-4a, C-6), 95.3 (C-8), 78.0 (C-3'), 55.9 (OMe), $28.1\left(\mathrm{Me}^{\prime} 2\right)$.

\section{Nerolidol (8)}

Oil. ${ }^{1} \mathrm{H}$ NMR $\left(300 \mathrm{MHz}, \mathrm{CDCl}_{3}\right): \delta 5.92(1 \mathrm{H}, \mathrm{dd}, \mathrm{H}-2)$, 5.24-5.04 (4H, m, H-1, H-6, H-10), 2.10-1.90 (6H, m,H-5, H-8, H-9), 1.68 (3H, s, Me-12), 1.60 (6H, s; Me-13, Me-14), 1.62-1.45 (2H, H-4), 1.28 (3H, s, Me-15). ${ }^{13} \mathrm{C}$ NMR $(75$ $\mathrm{MHz}, \mathrm{CDCl} 3$ ): $\delta 145.0$ (d, C-2), 135.5 (s, C-7), 131.4 (s, C11), 124.2 (d, C-6, C-10), 111.6 (t, C-1), 73.5 (s, C-3), 42.0 (t, C-4), 39.6 (t, C-8), 27.8 (q, Me-15), 26.6 (t, C-9), 25.7 (q, Me-13), 22.7 (t, C-5), 17.6 (q, Me-12), 16.0 (q, Me-14).

\section{0,11-epoxynerolidol (9)}

Oil. ${ }^{1} \mathrm{H}$ NMR (300 MHz, $\left.\mathrm{CDCl}_{3}\right): \delta 5.92(1 \mathrm{H}, \mathrm{dd}, J 17.3$ and $10.7 \mathrm{~Hz}, \mathrm{H}-2), 5.25-5.05$ (3H, m; H-1, H-6), 3.67 (1H, br t, $J$ 7.5 Hz, H-10), 2.20-1.95 (6H, m, H-5, H-8, H-9), 1.60 
(3H, s, Me-14), 1.60-1.45 (2H, H-4), 1.30, 1.29, $1.26(9 \mathrm{H}$, ss; Me-12, Me-13, Me-15). ${ }^{13} \mathrm{C} \mathrm{NMR} \mathrm{(300} \mathrm{MHz,} \mathrm{CDCl}_{3}$ ): $\delta 144.9(\mathrm{~d}, \mathrm{C}-2), 134.5$ (s, C-7), 124.2 (d, C-6), 111.7 (t, C1), 73.4 (s, C-3), 64.2 (d, C-10), 58.3 (s, C-11), 41.9 (t, C-4), 36.3 (t, C-8), 27.8 (q, Me-15), 27.3 (t, C-9), 24.9 (q, Me13), 22.7 (t, C-5), 18.7 (q, Me-12), 16.0 (q, Me-14).

\section{N-[2-(4-prenyloxyphenyl)ethyl]-tigliamide (10)}

mp $68-70^{\circ} \mathrm{C} . \mathrm{NMR}$ spectral data, reported in literature. ${ }^{11}$

\section{N-[2-(4-hydroxyphenyl)ethyl]-tigliamide (11)}

${ }^{1} \mathrm{H} \mathrm{NMR}\left(300 \mathrm{MHz}, \mathrm{CDCl}_{3}\right): \delta 7.05(2 \mathrm{H}, \mathrm{d}, J 8.5 \mathrm{~Hz} ; \mathrm{H}-$ 3, H-5), 6.79 (2H, d, J 8.5 Hz; H-2, H-6), 6.38 (1H, br q, $J$ 6.7 Hz, H-12), 5.60 (1H, br s, NH), 3.52 (2H, q, J6.8 Hz, H8), 2.77 (2H, t, J6.8 Hz, H-7), 1.78 (3H, br s, Me-14), 1.73 (3H, br s, Me-13).

\section{Hortiolide A (12)}

$\mathrm{C}_{27} \mathrm{H}_{32} \mathrm{O}_{7}, \mathrm{mp} 205-6^{\circ} \mathrm{C}(\mathrm{MeOH}) ;[\alpha]_{\mathrm{D}}+92^{\circ}(\mathrm{c}=0.55$, $\mathrm{CHCl3})$. IR $v_{\max } / \mathrm{cm}^{-1}: 1710,1630$. NMR data see Tables 2 and 4. EI-MS (probe) $70 \mathrm{eV}, m / z$ (rel. int.) : $468[\mathrm{M}]^{+}$(3),

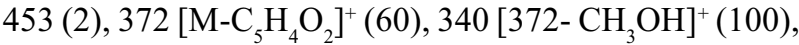
299 (5), 243 (5), 199 (8), 188 (10), 173 (6), 160 (30), 148 (15), 119 (15), 105 (21), 96 (20). Difference nOe experiments: mutual nOe effects were observed among $\mathrm{H}$ 9, Me-30, Me-19 and H-6; between Me-30 and Me-18; between $\mathrm{H}-5$ and Me-29.

\section{Hortiolide B (13)}

$\mathrm{C}_{27} \mathrm{H}_{30} \mathrm{O}_{8}$, oil. NMR data, see Tables 3 and 5. EI-MS (probe) $70 \mathrm{eV}, m / z$ (rel. int.) : $482[\mathrm{M}]^{+}(2), 440\left[\mathrm{M}-\mathrm{C}_{2} \mathrm{H}_{2} \mathrm{O}\right]$ (19), 425 (6), 344 [440- $\mathrm{C}_{5} \mathrm{H}_{4} \mathrm{O}_{2}$ ] (100), 329 (45), 312 (29), 284 (17), 267 (33), 251 (19), 204 (30), 189 (35), 160 (53), 129 (47), 95 (87). Difference nOe experiments: mutual nOe effects were observed among H-5, H-2 and Me-29; between $\mathrm{H}-2$ and H-15; among Me-19, Me-28, Me-30 and $\mathrm{H}-6$; between Me-30 and Me-18.

\section{References}

1. Waterman, P.G.; Grundon, M.F. eds. In Chemistry and Chemical Taxonomy of Rutales; Academic Press: New York, 1983.

2. Cuca Suarez, L.E.; Martinez Valderrama, J.C.; Delle Monache, F.; Rev. Col. de Quim. 1998, 27, 23.

3. Forero, E.; Gentry, A.H. ; Lista anotada de las plantas del Departamento del Chocò, Editora Guadalupe:Bogotà, 1989.

4. Correa de Barros, D.; Gottlieb, O.R.; Pimenta de Padua, A.; Phytochemistry 1975, 14, 2059.

5. Jacobs, H.; Ramdayal, F.; Reynolds, F.W.; Poplawski, J.; Mc Lean, S.; Can. J. Chem. 1986, 64, 580.

6. Tinto, W.F.; Mc Lean, S.; Reynolds, F.W.; J. Nat. Prod. 1992, $55,1676$.

7. Nakano, T.; Alonso, J.; Grillet, R.; Martin, A.; J. Chem. Soc. Perkin I 1979, 2107.

8. Nakano, T.; Tori, K.; Yoshimura, Y.; Rev. Latinoam. Quim. 1979, 10, 17.

9. Murray, R.D.H.; Mendez, J.; Brown, S.A.; The Natural Coumarins. Occurrence, Chemistry and Biochemistry, J.Wiley Sons Ltd: New York, 1982.

10. Steck, W.; Mazurek, M.; J. Nat. Prod. (Lloydia), 1972, 55, 418.

11. Weyerstahl, P.; Marschall, H.; Bork, W.R.; Rilk, R.; Liebigs Ann. Chem. 1994, 1043

12. Cuca Suarez, L.E.; Casabò, J.; Delle Monache, F.; Espinosa, E.; Miravitlles, C.; Annales de Quimica International Ed., 1998, 4-5, 307.

13. Daniewski, W.M.; Gumulka, M.; Danikiewicz, W.; Gluzinski, P.; Krajewski, J.; Pankowska, E.; Bloszyk, E.; Jacobson, U.; Norin, T.; Szafranski, F.; Phytochemistry 1993, 33, 1534.

14. Dreyer, D.L. In Isopentenoid in Plants. Biochemistry and Function; Nes, W.D.; Fuller, G.; Tsai, L-S. eds.; Marcel Dekker: New York, 1984.

15. Das, M.F.; Da Silva, G.F.; Gottlieb, O.R.; Biochem System. Ecol. 1987, 15, 85.

16. Champagne, D.E.; Koul, O.; Isman, M.B.; Scudler, G.G.E.; Towers, G.H.N.; Phytochemistry 1992, 3, 377.

17. Daniewski, W.M.; Gumulka, M.; Gluzinski, P.; Krajewski, J.; Sitkowski, E.; Drozdz, B.; Jacobsson, U.; Norin, T.; Szafranski, F.; Phytochemistry 1994, 36, 1001.

Received: September 19, 2001 Published on the web: May 9, 2002 